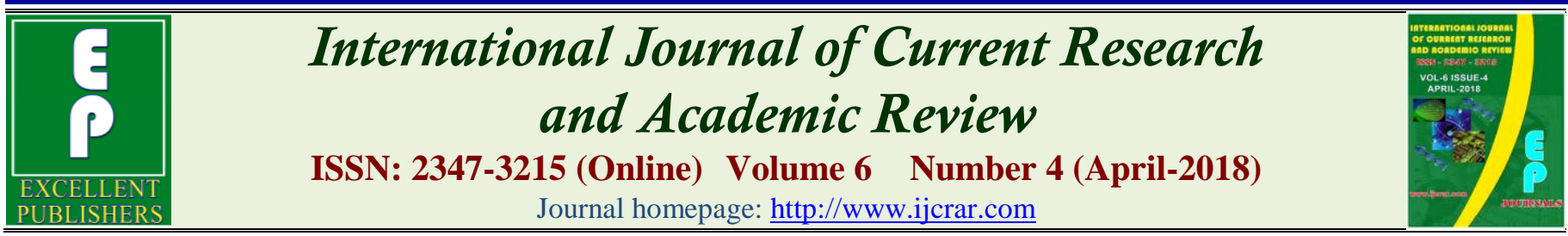

doi: https://doi.org/10.20546/ijcrar.2018.604.001

\title{
Genetic Parameters of Milk Yield in Bulgarian Dairy Synthetic Population Sheep
}

\author{
Jivko Krastanov ${ }^{1 *}$, Nevyana Stancheva ${ }^{2}$, Teodora Angelova ${ }^{1}$, Georgi Kalaydzhiev ${ }^{1}$, Stayka Laleva ${ }^{1}$ \\ and Daniela Yordanova ${ }^{1}$
}

${ }^{1}$ Agricultural Institute - Stara Zagora, Bulgaria,

${ }^{2}$ Agricultural Institute - Shumen, Bulgaria

*Corresponding author

\section{Abstract}

The purpose of the present study was to analyse the genetic variance (additive, dominance, epistatic) of milk yield and the resulting genetic effects in Bulgarian Dairy Synthetic Population (BDSP) sheep in the framework of an experiment for introduction of Chios and Lacaune sheep in the breeding and selection schedule of BDSP. A test-day model was used including daily milk yields as separate observation. The observed genetic variance was substantial, comprising 0.33 of the total variance. The proportion of the additive genetic variance was 0.23 , while that of nonadditive: 0.10 of the total variance. The observed genetic effects were statistically significant, and dominance genetic effect was positive (137.18). Additive genetic effect was also positive (27.86), and together with the dominance variance it constituted the major part of genetic variance. The epistatic genetic effect was negative (-33.15). The estimates of additive genetic effects and non-additive deviations for tested genetic groups showed diversity and deviations depending on the percentage of blood of the different breeds and pathways of genotypes' formation.
\end{abstract}

\section{Article Info}

Accepted: 07 March 2017

Available Online: 20 April 2018

\section{Keywords}

Additive and non-additive effects, Genetic parameters, Milk yield, Synthetic sheep populations, Testday model

\section{Introduction}

The efficiency of breeding systems in livestock husbandry is directed to seeking ways and methods for improving production performance and genetic gain. Depending on the breeding goal in sheep farming, new composite breeds, populations and lines are created for specific purposes - prolificacy, meat production, wool production with different wool quality, milk production and combined productivity (Rasali et al., 2006; Walkom et al., 2011). Bulgarian specialised sheep breeds also belong to this group. In the contemporary breed structure, the representatives of the Bulgarian Dairy Synthetic Population (BDSP) created in 2005 are the most numerous. BDSP is created by application of a system with various schedules for continuous hybridization (Hinkovski et al., 1979, 1984) on the background of the possibility for synthesis of an additive component for high milk yield and prolificacy and manifestation of a heterosis effect for these traits resulting from the genetic interaction of this crossbreeding technique. Breeding schedules use as a base Merino, half-Merino and dairy Bulgarian ewes and rams from highly-productive dairy breeds: East Friesian (EF) and Awassi (AW) and Bulgarian Blackhead Pleven (BP) and Stara Zagora (SZ). After obtaining the desired crossbreds, schedules were closed, nucleus herds of the population were created in the 1980s and then, in-herd 
breeding is practiced. The BDSP production profile is close to that of EF sheep, but they are more resistant, more easily adapted and non-exigent with respect to the climate of the environment, appropriate for machine milking, with well-developed and formed udder. At present, the most representative consolidated herds from the National Genetic Pool of the population are housed in the agricultural institutes and experimental stations of the Agricultural Academy:- Experimental Base State Enterprise to the Shoumen Agricultural Institute, Institute of Animal Sciences - Kostinbrod, Agricultural Institute-Shoumen; The Institute of Agricultural Sciences - Kostinbrod; Agricultural Institute - Stara Zagora and Agricultural Institute - Karnobat (Stancheva et al., 2016). These are the main flocks where selection for high milk yield and prolificacy has been carried out during the past years in compliance to selection goals and after periodical analysis of changes in main selection traits, their variability and causing components during the different stages of development of formed genetic structures (Boikovski et al., 2003 ${ }^{\mathrm{a}}, 2003^{\mathrm{b}}, 2005,2006$; Hinkovski et al., 2008; Ivanova and Raicheva, 2008; Ivanova, 2013; Lazarov et al., 2002; Nedelchev et al., 2003; Raicheva et al., 2003; Raicheva and Ivanova, 2010, 2011 ab; Stancheva, 2003; Stancheva et al., 2006, 2014). The authors reported that during the last years, average milk yields for a 120-day lactation were slightly decreased $(951-1151)$, which did not correspond to the genetic potential of dairy animals ranging between 150 2001 . In all flocks of agricultural institutes, the variation of milk yield was high $(17.59 \%-34.87 \%)$ indicating that future selection work should be directed to its increase. This, of course, is possible under optimum conditions of feeding and housing, whose provision in fact is difficult during the recent years.

Being the youngest one, the Bulgarian dairy synthetic population is undergoing continuous development, improvement and genetic renewal, especially in the private sector where the phenotype and genetic diversity are significant and productivity levels substantially different. The selection in these flocks is managed by four non-governmental breeding organisations, whose activity is mainly confirmed to control on production traits due to a number of reasons and problems. This is the prerequisite for initial gathering of information but is not sufficient for the development and consolidation of the population. The attempts of farmers to speed-up the genetic progress enhanced the interest to introduction of new genetic variance from Lacaune and Chios breeds, and in many BDSP flocks in the country, uncontrolled introduction of blood from these and other dairy breeds is currently in course, probably resulting from new processes of genetic changes with unclear results from the point of view of set goals. Goyache et al., (2003) and Malhado et al., (2008) believe that the investigations on genetic changes that occur in population structure are essential not only as an instrument for management of genetic interactions, but also are at the background of analysis and evaluation of results from implemented selection programmes, and that the negligence of data about introduced new animals with a different origin could lead to over- or underestimation of important traits, erroneous interpretations and prognoses about the future development. One of the principal causes for genetic loss in synthetic populations is the absence of a reliable and working schedule for crossbreeding of flocks that can guarantee maximum heterosis and genetic superiority over source forms. El Fadili and Leroy (2001) affirmed that crossbreeding between local and high-productive breeds could enhance production performance through profiting from additive and non-additive genetic variance. Tibbo (2006) presents aspects associated to the importance of preserving the adjustment to local conditions during production traits improvement using different crossbreeding schedules. Baer et al., (2012) analysed the genetic effects from crossing local breeds with Lacaune and East Friesian sheep in the Slovak Republic. Lobo et al., (2009) discussed the genetic parameters of growth and reproductive performance traits in meat sheep from a multibreed population reared in Brazil. Safari and Fogarty (2003) summarised a large part of studies on genetic parameters of selection traits in different breeds. Now, the studies on breeding BDSP sheep with regard to breed composition and introduction of Chios and Lacaune blood in order to improve the milk yield in Bulgaria are limited (Boikovski et al., 2013; Stancheva et al., 2014) and are only performed in scientific experiments with nucleus flocks of Agricultural Academy establishments.

The purpose of the present study was to analyse the genetic variance (additive, dominance, epistatic) of milk yield and resulting genetic effects in BDSP sheep in the framework of an experiment for introduction of Chios and Lacaune sheep in the breeding and selection schedule of BDSP.

\section{Materials and Methods}

The study subjects were ewes from the Bulgarian Dairy Sheep Population (BDSP) flocks of Experimental Base State Enterprise to the Agricultural institute - Shoumen born in the period $2007-2012$ with available records for 
the main selection trait - milk yield. The flock was created using a specific modified schedules using as a base ewes from the Northeast Bulgarian merino breed mated with East Friesian rams and introduction of blood from Awassi and Blackhead Pleven breeds, and at a later stage: from the Stara Zagora breed. There is a genealogical structure built as early as the time of application of crossbreeding schedules. Internal breeding is practiced for more than 30 years using locally produced rams with application of homogenous selection with moderate inbreeding level. Ewes were inseminated artificially according to individual mating plan. They were reared in stalls and on pastures in a semi-intensive system. Ewes were inseminated at the age of 18 months after flock formation. The annual replacement rate was about $30 \%$. The reproduction was performed once per year in June-July. The lambing occurred from the last half of November to the end of December. Milking was machine, and lactation period was from 150 to 180 days. The suckling period was 55-60 days with a recent tendency to reduce it to 40-45 days. For higher genetic diversity and introduction of high milk yield genes, one Chios and one Lacaune ram were purchased in 2007. In 2008, another Lacaune ram was purchased and it had no kinship with the first sire. Ewes having shown a high level of inbreeding at subsequent insemination with sires from the flock and ewes with unknown origin of one of the parents were submitted to crossbreeding. The Chios ram was used only in 2008 and has left no male offspring. The two Lacaune rams have male offspring with $25 \%$ and $37.5 \%$ blood.

\section{Genetic structure of the flock}

Using the pedigree book databases, the pedigrees of 601 sheep were analysed with regard to the parental and ancestor breeds for every animal back to the $3^{\text {rd }}$ pedigree level inclusive according to the schedule: ${ }^{\mathrm{D}} \mathrm{D}$ $\left[\left(q(\mathrm{DDD} x \mathrm{SDD}) \mathrm{x}{ }^{\lambda}(\mathrm{DSDxSSD})\right] \quad \mathrm{x} \quad{ }^{\lambda} \mathrm{S}\right.$ [(q(DDSxSDS)x ${ }^{\wedge}$ (DSSxSSS)]. Genotypes involving the Bulgarian Synthetic Dairy Population (BDSP); Lacaune (L); Chios (Ch); East Friesian (EF) breeds and animals with unknown origin of one of parents were registered. All available relationships between animals were established and the resultant kinship matrix 878 individuals (pedigrees), out of which 277 basic and 601 non-basic. On the basis of gathered information, the genetic structure of the flock comprised 33 genotypes, 30 of which had complete pedigree records. The genetic groups in the flock were identified depending on the proportion of blood of the separate breeds in individual genotypes (Stancheva et al., 2016).
Genetic variance analysis (additive, dominance, epistatic), analysis of crossing genetic effects on milk yield

The total number of test-day milk yield records was 5023. The study comprised 4895 TMY records of ewes of known origin with 1 to 6 lactations. TMY data are obtained from monthly controls during the lactation (30 monthly controls between 2009 and 2014) according to the AC method as per ICAR nomenclature.

On the basis of analysed information for the breed of parents and ancestors of each sheep was generated a variable with individual information for its genetic origin. This allows for the correct identification of alleles from the different paternal or maternal populations in individual genotypes. The total of 30 studied genotypes (18 from internal breeding of BDSP and 6 from each of experiments with Lacaune and Chios) included blood from East Friesian, Lacaune, Chios and BDSP sheep.

For unbiased estimation of the variance, a model based on the general genetic hypothesis was used. The analysis of experimental data relied on the assumption that the genetic variance in the studied population was caused by both the additive effect of individuals and by the nonadditive effects of the variation in individual genotypes emerging from crossing of breeds involved in pedigrees of animals. The environmental effects resulted from the fact that only data from a single nucleus flock were analysed taking into consideration the information for the number of lactation, year and month of test-day milk yield control along with the permanent environmental effect. In the used test-day model, individual TMY were included as separate observations.

The initial analysis of genetic variance and estimations of genotypes in the different genetic groups was done using a mixed linear model as followed:

$y=X+Z+e$

b u

Where:

$\mathrm{y}$ - observation vector for milk amount $(\mathrm{mL})$ for the respective test day of each animal participating in the analysis;

b - fixed effects vector - year/month for each test day and each subsequent lactation, regression effect of age (days) at the time of test day, number of days in lactation 
to the time of the test-day during the current lactation period;

$\mathrm{u}$ - random effects vector - genotype with expected estimate of the variance caused by non-additive genetic effects (dominance and epistatic), animal with expected estimate of variance caused by the additive genetic effect, permanent environmental effect;

e - random effect of non-observed factors;

$\mathrm{X}$ and $\mathrm{Z}$ - matrices corresponding to described variables.

The analysis of genetic effects - additive, dominance and epistatic was done on the basis of the hypothesis in the model of Koch et al., (1985):

\begin{tabular}{|c|c|}
\hline$=m+(\alpha-\alpha) \alpha+\delta d+(\alpha$ & $-\alpha) \alpha \alpha$ \\
\hline $\begin{array}{lll}i & j & i j\end{array}$ & $i$ \\
\hline
\end{tabular}

Where:

$\alpha$ - the proportion of genes from a given population in a given genetic group;

$\delta \quad-$ The probability that a given randomly selected locus of a randomly selected animal from a given genetic group would have an allele from one or another experimental population.

The models were computed with software products VCE by Kovac et al., (2008), PEST by Groeneveld et al., (2002) and CBE by Wolf (1996).

\section{Results and Discussion}

In Bulgaria, milk yield of sheep from the Bulgarian Synthetic Dairy Population is determined for a standard 120-day period and average milk yield is calculated by division of total milk amount to lactation period in days. The reported average milk yields for the sheep from the studied flock were 0.7991 from first lactation and 0.7741 from second and subsequent lactations (Boikovski et al., 2006). Stancheva and Staikova (2013) investigated the relatiohsip between body condition scores and milk yields of sheep in 2011-2012 and reported average milk yields between 0.8991 - 0,934 1 (BCS 3-3.5 и над 3.5 на $1^{\text {-ва }}$ лактация) и $0.8481-0.9111$ (BCS 3-3.5 and > 3.5 in sheep in second and subsequent lactations).
Modern trends for evaluation of the breeding value in sheep farming are based on test-day milk yields - test day model (Bauer et al., 2012; Gutierrez et al., 2007; Horstick, 2001; Ligda et al., 2002; Oravcová et al., 2005, 2006; Othomane et al., 2002; Serrano et al., 2001) as it is more accurate in determining environmental effects (parity number, lambing age, number of born or weaned lambs, stage of lactation etc.) related to lactation. The obtained test-day yield (TDY) of $0.8961 \pm 0.34$ (Table 1) was higher that those reported for breeds Awassi - 0.796 1 (Jawasreh and Khasawneh, 2007), Tsigai and Improved Valachian - 0.6201 amd 0.6301 (Oravcova et al., 2005), Istrian Pramenka - 0.7081 (Komprej et al., 2003), BlackFaced and Blond-Faced Latxa - 0.820 1 and 0.7401 (Gabina et al., 1993). The TDY of specialised dairy breeds were significantly higher: East Friesian - 2.3301 (Hamann et al., 2004), Assaf - 1.9301 (Pollot and Gootwine, 2004), Lacaune - 1.6401 (Barillet et al., 2001; Berger, 2004). The comparison of milk yields of BDSP sheep bs high-productive foreign breeds should take consideration of the existing differences with regard to the duration of suckling period (about 60 days), standard lactation period (120 days), the level of nutrition and the production system (semo-intensive and extensive in the major part of the provate sector). The large variation between the minimum $(0.297$ 1) and maximum (3.143 l) daily milk yield suggested a potential for increasing the genetic potential of animals.

The results from the initial analysis of the variance (Table 2) showed that the main genetic variance resulted from the individual variability - 21042.22 vs 9115.99 for variance resulting from the heterosis. The genetic variance resulting from the different blood of individuals was only 0.10 of the total variance, but when compared to the individual genetic variance $(0.23)$ and genotypes (total of 0.33 ), it comprised almost one-thrid from the total genetic variance. This is undoubtedly a desired and anticipated effect from the point of view of set experimental goals e.g. increases in milk yield genetic variance. With regard to milk yield estimation on the basis of test-day yield (TDY), similar genetic variance values and respective proportions $\left(h^{2}\right)$ were rarely reported in sheep. Most of them referred to the total heritability and ranged from 0.11 to 0.35 depending on the used models (Bauer et al., 2012; Gutierez et al., 2007; Hamman et al., 2004; Ligda et al., 2002, 2003; Oravcova, 2007; Oravcova et al., 2005, 2006, 2007, 2008, 2015). 
Table.1 General mean of test-day milk yield (L).

\begin{tabular}{lc}
\hline $\begin{array}{l}\text { descriptive } \\
\text { statistics }\end{array}$ & TDY, L \\
\hline observations & 4895 \\
min & 0.297 \\
max & 3.143 \\
mean & 0.896 \\
S.D. & 0.34 \\
C.V. $(\%)$ & 38 \\
\hline
\end{tabular}

Table.2 Genetic variance and respective ratios for the trait milk yield

\begin{tabular}{|l|c|c|c|}
\hline Source of variation & Variance & $\begin{array}{c}\text { Corresponding } \\
\text { ratios, (h2) }\end{array}$ & Standard Error \\
\hline Residual & 61252.99 & 0.67 & \pm 0.035 \\
\hline Animal & 21042.22 & 0.23 & \pm 0.039 \\
\hline Genotype & 9115.99 & 0.10 & \pm 0.015 \\
\hline
\end{tabular}

Table.3 Genetic effects (on diagonal) and correlations (above diagonal) among the parameters under evaluation in the studied population

\begin{tabular}{|c|c|c|c|c|}
\hline Parameter & Mean & Additive & Dominance & Add.X Add. \\
\hline Mean & $901.24 \pm 0.37 * *$ & -0.78 & -0.80 & 0.40 \\
\hline Additive & & $27.86 \pm 0.94 * *$ & 0.94 & -0.87 \\
\hline Dominance & & & $137.18 \pm 0.89 * *$ & -0.80 \\
\hline Add.X Add. & & & & $-33.15 \pm 0.82 * *$ \\
\hline
\end{tabular}


Int.J.Curr.Res.Aca.Rev.2018; 6(4): 1-10

Table.4 Estimation of the genetic effects of the different genetic groups

\begin{tabular}{|c|c|c|c|c|c|c|c|c|}
\hline & \multirow{3}{*}{ Genetic group } & \multicolumn{2}{|c|}{ genotypes } & \multirow{3}{*}{$\mathbf{n}$} & \multirow{3}{*}{$\begin{array}{l}\text { additive } \\
\text { means }\end{array}$} & \multirow{3}{*}{$\begin{array}{c}\text { non- } \\
\text { additive } \\
\text { variance }\end{array}$} & \multirow{3}{*}{$\begin{array}{c}\text { Group } \\
\text { additive } \\
\text { means }\end{array}$} & \multirow{3}{*}{$\begin{array}{c}\text { non- } \\
\text { additive } \\
\text { variance }\end{array}$} \\
\hline & & 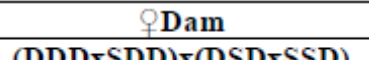 & $\frac{\text { Sire }}{4 \sin }$ & & & & & \\
\hline & & $(\mathrm{DDD} \mathbf{x} \mathrm{SDD}) \mathbf{x}(\mathrm{DSD} \mathbf{x S S})$ & $(\mathrm{DDS} x \mathrm{SDS}) \mathbf{x}(\mathrm{DSS} \mathbf{x S S S})$ & & & & & \\
\hline \multirow{18}{*}{ 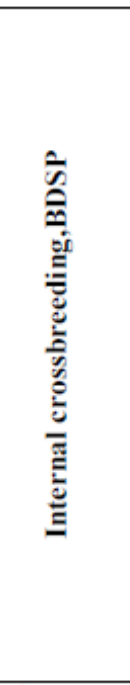 } & $100 \%$ BDSP & $(\mathrm{BDSP}) \mathbf{x}(\mathrm{BDSP})$ & $(\mathrm{BDSP}) \mathbf{x}(\mathrm{BDSP})$ & 324 & 862.9 & -33.0 & 862.9 & -33.0 \\
\hline & \multirow{4}{*}{$87 \%$ BDSP $12.5 \%$ EF } & $(\mathrm{BDSP}) \times(\mathrm{BDSP})$ & $((\mathrm{BDSP}) \mathbf{x}(\mathrm{BDSPxEF}))$ & 2 & 890.7 & -9.2 & \multirow{4}{*}{851.3} & \multirow{4}{*}{-49.3} \\
\hline & & $(\mathrm{BDSP}) \mathbf{x}(\mathrm{BDSP})$ & $(($ BDSPxEF $) x(B D S P))$ & 34 & 837.2 & -63.2 & & \\
\hline & & $(($ BDSP)x(BDSPxEF)) & $(\mathrm{BDSP}) \times(\mathrm{BDSP})$ & 27 & 841.5 & -59.2 & & \\
\hline & & $((B D S P x E F) x(B D S P))$ & (BDSP) $\mathbf{x}$ (BDSP) & 22 & 881.5 & -19.2 & & \\
\hline & \multirow{5}{*}{$75 \%$ BDSP $25 \%$ EF } & (BDSP) $\mathbf{x}($ BDSP) & (BDSP)x(EF) & 11 & 728.2 & -177.5 & \multirow{5}{*}{818.4} & \multirow{5}{*}{-85.9} \\
\hline & & $(\mathrm{BDSP}) \mathbf{x}(\mathrm{EF})$ & $(\mathrm{BDSP}) \times(\mathrm{BDSP})$ & 8 & 851.3 & -52.5 & & \\
\hline & & $(($ BDSP) $\mathbf{x}($ BDSPxEF $))$ & $(($ BDSP) $\mathbf{x}($ BDSPxEF $))$ & 1 & 897.3 & -5.5 & & \\
\hline & & $((\mathrm{BDSP}) \mathbf{x}(\mathrm{BDSP} \mathrm{xEF}))$ & $((\mathrm{BDSP} \times \mathrm{EF}) \times(\mathrm{BDSP}))$ & 4 & 942.0 & 38.5 & & \\
\hline & & $((B D S P x E F) x(B D S P))$ & $((B D S P x E F) x(B D S P))$ & 5 & 849.6 & -53.5 & & \\
\hline & \multirow{6}{*}{$62.5 \%$ BDSP $37.5 \%$ EF } & $((B D S P) x(B D S P x E F))$ & $($ BDSP) $\mathbf{x}(\mathbf{E F})$ & 9 & 853.4 & -52.7 & \multirow{6}{*}{883.1} & \multirow{6}{*}{-22.6} \\
\hline & & $((B D S P x E F) x(B D S P))$ & $(\mathrm{BDSP}) \mathbf{x}(\mathbf{E F})$ & 6 & 784.7 & -120.7 & & \\
\hline & & (BDSP) $\mathbf{x}($ EF $)$ & $((B D S P) \mathbf{x}(B D S P x E F))$ & 2 & 908.5 & 4.3 & & \\
\hline & & $(\mathrm{BDSP}) \mathbf{x}(\mathbf{E F})$ & $(($ BDSPxEF $) \times(B D S P))$ & 1 & 1395.5 & 490.3 & & \\
\hline & & $((B D S P) x(B D S P x E F))$ & $((B D S P x E F) x(B D S P x E F))$ & 2 & 906.4 & 0.3 & & \\
\hline & & $((B D S P x E F) x(B D S P x E F))$ & $(($ BDSPxEF $) \times(B D S P))$ & 1 & 1130.9 & 225.3 & & \\
\hline & \multirow[b]{2}{*}{$50 \%$ BDSP $50 \%$ EF } & $(\mathrm{BDSP}) \mathbf{x}(\mathrm{EF})$ & $(\mathrm{BDSP}) \mathbf{x}(\mathrm{EF})$ & 9 & 806.0 & -101.9 & \multirow{2}{*}{797.0} & \multirow{2}{*}{-110.3} \\
\hline & & ((BDSPxEF)x(BDSPxEF)) & $(\mathrm{BDSP}) \mathbf{x}(\mathbf{E F})$ & 2 & 756.5 & -149.9 & & \\
\hline \multirow{4}{*}{ 郑 } & \multirow[b]{2}{*}{$50 \%$ BDSP $50 \%$ Lacaune } & (BDSP) $\mathbf{x}($ BDSP) & $(\mathrm{L}) \mathbf{x}(\mathrm{L})$ & 41 & 1037.8 & 83.8 & \multirow{2}{*}{1031.1} & \multirow{2}{*}{77.1} \\
\hline & & $(\mathrm{BDSP}) \mathbf{x}(\mathrm{L})$ & $(\mathrm{BDSP}) \mathbf{x}(\mathbf{L})$ & 1 & 757.1 & -196.3 & & \\
\hline & \multirow{2}{*}{$75 \%$ BDSP $25 \%$ Lacaune } & $($ BDSP) $x$ (BDSP) & $($ BDSP) $x(\mathbf{L})$ & 2 & 1006.1 & 43.0 & \multirow{2}{*}{956.1} & \multirow{2}{*}{-7} \\
\hline & & $(\mathrm{BDSP}) \mathbf{x}(\mathrm{L})$ & $(\mathrm{BDSP}) \times(\mathrm{BDSP})$ & 10 & 946.1 & -17.0 & & \\
\hline \multirow{2}{*}{ 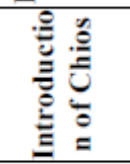 } & $\mathbf{5 0} \%$ BDSP $50 \%$ Chios & $(\mathrm{BDSP}) \times(\mathrm{BDSP})$ & $(\mathrm{Ch}) \mathbf{x}(\mathrm{Ch})$ & 15 & 931.3 & 30.8 & 931.3 & 30.8 \\
\hline & $75 \%$ BDSP $25 \%$ Chios & $(\mathrm{BDSP}) \mathbf{x}(\mathbf{C H})$ & $(\mathrm{BDSP}) \mathbf{x}(\mathrm{BDSP})$ & 13 & 1076.1 & 177.8 & 1076.1 & 177.8 \\
\hline & & $(($ BDSP)x(BDSPxEF)) & $(\mathrm{L}) \mathbf{x}(\mathrm{L})$ & 9 & 1107.2 & 119.3 & & \\
\hline 苞 & $\begin{array}{c}50 \% \text { Lacaune } 37.5 \% \text { BDSP } \\
12.5 \% \text { EF }\end{array}$ & $((B D S P x E F) x(B D S P))$ & $(\mathbf{L}) \mathbf{x}(\mathbf{L})$ & 9 & 1065.7 & 77.3 & 1086.5 & 98.3 \\
\hline$\overline{\bar{c}}$ & & $((B D S P x(B D S P x E F))$ & $(\mathrm{Ch}) \times(\mathrm{Ch})$ & 3 & 668.0 & -26.0 & & \\
\hline$\stackrel{\mathscr{E}}{\mathscr{E}}$ & $50 \%$ Chios $37.5 \%$ BDSP $12.5 \%$ EF & $(($ BDSPxEF $) x(B D S P))$ & $(\mathrm{Ch}) \times(\mathrm{Ch})$ & 2 & 925.5 & 17.0 & 771.0 & -8.8 \\
\hline$\frac{}{0}$ & $\begin{array}{c}\mathbf{5 0} \% \text { Lacaune } \mathbf{2 5} \% \text { BDSP } \\
\mathbf{2 5} \% \text { Chios }\end{array}$ & $(\mathrm{BDSP}) \mathbf{x}(\mathrm{Ch})$ & $(\mathbf{L}) \mathbf{x}(\mathbf{L})$ & 7 & 954.3 & -50.9 & 954.3 & -50.9 \\
\hline$\underline{E}$ & $\begin{array}{c}62.5 \% \text { BDSP } 25 \% \text { Lacaune } \\
12.5 \% \text { Chios } \\
\end{array}$ & $((\operatorname{BDSPxCh}) \mathbf{x}(\mathrm{L}))$ & $(\mathrm{BDSP}) \times(\mathrm{BDSP})$ & 4 & 846.5 & -119.3 & 846.5 & -119.3 \\
\hline
\end{tabular}


According to Bauer et al., (2012) progress in milk yield estimates could be achieved with a mixed linear model which included the respective number of different traits taking consideration of the advantages of the heterosis effect in crossbred animals.

The analysis of genetic parameters (Table 3) showed a statistically significant and sustainable positive dominance (137.18). The additive genetic effect estimate is also positive (27.86), it, together with the dominance one made up the main genetic variance. It could be affirmed that the values of these two parameters suggested positive tendencies in the breeding of this nucleus flock. In support of this thesis, both parameters were in close correlation (0.94). The negative values of the epistatic genetic effect (-33.15) was expected from the point of view of the fact, that predominant number of sheep in the population were animals whose genotypes were formed by crossbreeding after the first generation. These results should not be confusing for flock breeders because the estimated value of the epistatic effect was $1 / 5$ of the genetic variance. The strong negative correlations between the epistatic genetic effect and additive and dominance effects $(-0.87$ and -0.80 , respectively) showed a clear antagonism between these parameters. In our view, the more precise breeding would be beneficial for the increase in dominance homozygocity of the flock and the reduction of the influence of the epistatic effect could be higher than the theoretically expected one. Pollot and Goodwin (2001) believed that the low additive genetic variance level and milk yield heritability for Improved Awassi sheep were not due to a factor from the database but could be partly attributed to dominance and epistasis and reflect the real genetic effect in the studied population. Investigations on the additive genetic effect and milk yield demonstrated that it was only $10 \%$, while $90 \%$ was influenced by environmental factors, underlining the important role of production system and feeding (Oravcova et al., 2006).

Estimates of additive genetic effects and non-additive deviations for established genetic groups (Table 4) show a diversity and deviation depending on the percentage of blood of the different breeds and the pathway of genotype formation. In general, the largest genetic group (100\% BDSP), product of long-tern internal breeding, exhibited negative (probably epistatic) non-additive genetic effect (-33). In groups with different proportion of EF blood, the values of the additive and epistatic nonadditive effects varied within a broad range (from 797.0 to 883.1 for the former and from -22.6 to -110.3 for the latter). It could be summarised that a sustainable genetic trend of dominance has resulted for the major part of the population (862.9) along with weak epistatic interactions. It should be noted that all genotypes descending from sires with 50\% EF blood had negative deviations for non-additive genetic effects. According to the results, despite the exceptions, the maintenance of $37.5 \%$ EF blood had a beneficial additive effect (883.1) and appeared to contribute significantly in a positive effect, nevertheless, this hypothesis should not be favourised due to exceptions. Obviously, priority in future work should be given to unbiased estimates of breeding value of individuals, which would result in a more efficient choice of candidates for selection.

The selection experiment with Lacaune gave mainly positive results with regard to the non-additive deviation in F1 crosses with $50 \%$ blood, as the genetic groups exhibited increased milk yield by almost $20 \%$ compared to the additive population mean and positive nonadditive deviation (probably dominance). The internal breeding of the 75\% BDSP25\% Lacaune group resulted in reduction of the positive additive effect probably associated to the loss of dominance and appearance of a weak negative epistatic effect.

The experiment with Chios showed a positive additive effect in F1 crosses (931.3), which could be attributed to the desired dominance between the two breeds, being preserved or even increased after the subsequent crossbreeding (1076.1 for the 75\% BDSP $25 \%$ Chios group).

In three-breed crosses, the participation of the three breeds in breeding schedules led to substantial negative epistatic gene interactions (-119.3 for the $62.5 \%$, BDSP $25 \%$, Lacaune $12.5 \%$, Chios group and -50.9 for $50 \%$, Lacaune $25 \%$, BDSP $25 \%$, Chios sheep). The positive possible dominance in 50\% Lacaune $37.5 \%$ BDSP 12.5\% EF group (98.3) and additive effect (1086.5) indicated a good combination among the different.

The analyses demonstrated that along with the heterosis, the efficiency of the evaluation of genetic potential of animals in selection schedules was also important. Of course, the individual combination ability which is possibly important for the obtained results should not be underestimated.

This is the first case, where the genetic parameters of milk yield in BDSP sheep have been established from the point of view of the composite nature of the population 
using a test-day model. The structure of available data allowed obtaining reliable conclusions from the analysis.

A considerable genetic variance was established -0.33 of the total variance. The share of the additive genetic variance was 0.23 while that of the non-additive: 0.10 of the total variance.

Statistically significant genetic effects were observed with positive dominance genetic effect (137.18). The estimate of the additive genetic effect was also positive (27.86), and together with the dominance effect, they formed the main genetic variance. The epistatic genetic effect was negative (-33.15).

There was a sustainable genetic trend of dominance (862.9) and weak negative epistatic interactions in the main part of the population and in animals with $37.5 \%$ EF blood (883.1).

It could be affirmed that the observed genetic variance provides broad opportunities for genetic progress both through pure-breeding and through introduction of genetic component from the Chios or Lacaune sheep breeds.

The present study was realised with the support of Project Ж 113, Analysis of genetic diversity in Bulgarian sheep populations" funded by the Agricultural Academy.

\section{References}

Barillet F., Marie C., Jacquin M., Lagriffoul G., Astruc J.M. (2001): The French Lacaune dairy sheep breed: use in France and abroad in the last 40 years. Livest. Prod. Sci., 71, 17-29.

Bauer, J., Milerski, M., Přibyl, J., Vostrý, L. 2012. Estimation of genetic parameters and evaluation of test-day milk production in sheep. Czech J. Anim. Sci., 57, (11): 522-528.

Berger Y.M. (2004): Breeds of sheep for commercial milk production. In: Proceedings of 10th Great Lake Dairy Sheep Symposium. Hudson, Wisconsin. University of Wisconsin-Madison. 14-20.

Boikovski, St., G. Stefanova, N. Stancheva. 2006. Milk Yield for milking period in the Sheep from the Newly Created Milk Breed in Bulgaria, Bulgarian Journal of Agricultural Science, 12, 1, 145-152.

Boikovski, St., G. Stefanova, N. Stancheva. 2013. Results of the introduction of the breeds Lacaune and Chios into the schemes for improvement of the Bulgarian Dairy Synthetic Population, Sheep News,
1-2, 16-23 (Bg).

Boikovski, St., N. Stancheva, G. Stefanova, D. Dimitrov. $2003^{\mathrm{a}}$. Influence of Some Factors of the Milk Composition and the Yield of Trait of Sheep from The Newly Created Milk Sheep Breed, Bulgarian Journal of Agricultural Science, 9, 2, 243-249.

Boikovski, St., N. Stancheva, G. Stefanova, D. Dimitrov. $2003^{\mathrm{b}}$. Influence of Some Factors on Biological Prolificacy in Sheep from The Newly Created Milk Sheep Breed, Bulgarian Journal of Agricultural Science, 9, 3, 391-395.

Boikovski, St., N. Stancheva, G. Stefanova, D. Dimitrov. 2005. Milk Composition of the Sheep from Newly Created Milk Sheep Breed, Bulgarian Journal of Agricultural Science, 11, 5, 619-632.

El Fadili M and Leroy P., L. 2001. Estimation of additive and non-additive genetic parameters for reproduction, growth and survival traits in crosses between the Moroccan D'man and Timahdite sheep breeds. J Anim Breed Genet 118:341353.

Gabina D., Arrese F., Arranz J., Beltran de Heredia I. (1993): Average milk yields and environmental effects on Latxa sheep. J. Dairy Sci., 76, 11911198.

Goyache, F., Gutiérrez, J.P., Fernández, I., Gómez, E., Alvarez, I; Díez, J., Royo, L.J. Using pedigree information to monitor genetic variability of endangered populations: the Xalda sheep breed of Asturias as an example. Journal of Animal Breeding and Genetics, v. 120, p. 95-105, 2003.

Groeneveld. E., M. Kovac and T. Wang. 2002. PEST 32 MB VERSIONS 4.2.3, Multivariate Prediction and Estimation, CYGWIN_98-4.10 1.3.2<0.39-32>, Department of Animal Sciences University of Illinois.

Guti'errez, P., J., Legaz, E., Goyache, F. 2007. Genetic parameters affecting 180-days standardised milk yield, test-day milk yield and lactation length in Spanish Assaf (Assaf.E) dairy sheep Small Ruminant Research 70: 233-238.

Hamann, H., A. Horstick, A., Wessels, A., Distl, O. 2004. Estimation of genetic parameters for test day milk production, somatic cell score and litter size at birth in East Friesian ewes. Livestock Production Science, Volume 87, Issues 2-3, Pages 153-160.

Hinkovski TZ., E. Raicheva, N. Metodiev, 2008. Estimation of productivity of ewes from the Bulgarian Dairy Synthetic Population. Animal Science, № 3, 35-41. (Bg)

Hinkovski, Tz, P. Donchev, D. Dochevski, 1979. Diary sheep breeding and sheep management technologies, Zemizdat, Sofia, 213 (Bg). Hinkovski, 
Tz., A. Stoyanov, P. Donchev and S. Boikovski, 1984. Methodical instructions for creation of synthetic sheep population and technologies of raisin. Agric. Academy, Sofia, 37 pp. (Bg).

Horstick, A., 2001. Genetic analysis of milk performance and linear type traits in East Friesian and Black and Brown milk sheep. Dissertation. Tierärztlich Hochschule, Hannover.

Ivanova, T., 2013. Milk production of ewes from Synthetic Popuation Bulgarian Milk in the flock of IAS - Kostinbrod. Ph D Thesis, Kostinbrod, pp.139. (Bg)

Ivanova, T., E. Raicheva, 2008. Assessment the effect of some factors on lactation. Conference Proceedings "80 years Agrarian Sciences in the Rhodopes", 6771. $(\mathrm{Bg})$

Jawasreh K.I.Z. and A.Z. Khasawneh,2007. Genetic evaluation of milk production traits in Awassi sheep in Jordan. Egyptian J. of Sheep and Goat Sciences, Vol 2(2): 83-100.

Koch, R. M., G. E. Dickerson, L. V. Cundiff, K. E. Gregory 1985. Heterosis Retained in Advanced Generations of Crosses among Angus and Hereford Cattle, JAS Vol. 60 No. 5, p. 1117-1132

Komprej A., Gorjanc G., Malovrh Š., Kompan D., Kovač M. (2003): Test day model and genetic parameters in Slovenian dairy sheep. In: Proceedings of the 54th Annual Meeting of the EAAP, Rome, Italy. 351.

Kovac, M., E. Groeneveld, A. Garcia - Cortez. 2008. VCE - 6, Version 6.0.2, MS - Windows Windowsx86_32- gfor.

Lazarov, V., L. Mihailova, M. Iliev, 2002. Creation of population of sheep with increased milk yield. Animal Science, №6, 11-13. (Bg) Ligda, Ch., Gabriilidis, G., Georgoudis, A., 2002. Estimates of genetic parameters for test day somatic cell counts in Chios dairy sheep. In: Proceedings of the Seventh World Congress on Genetics Appl. to Livest. Prod., Montpellier, France, CD-ROM Communication No. 09-21.

Ligda C., Papadopoulos T., Mavrogenis A., Georgoudis A. Genetic parameters for test day milk traits and somatic cell counts in Chios dairy sheep. In: Gabiña D. (ed.), Sanna S. (ed.). Breeding programmes for improving the quality and safety of products. New traits, tools, rules and 12 organization. Zaragoza: CIHEAM, 2003. p. 55-59 (Options Méditerranéennes: Série A. Séminaires Méditerranéens; n. 55).

Lôbo, O., B., M., A., Lôbo, B., N., R., Paiva, R., S., Oliveira, P., M., S., Facó, O. 2009. Genetic parameters for growth, reproductive and maternal traits in a multibreed meat sheep population. Genetics and Molecular Biology, 32, 4, 761-770.

Malhado, C.H.M., Carneiro, P.L.S., Pereira, D.G., Martins Filho, R. Progresso genético e estrutura populacional do rebanho Nelore no estado da Bahia. Pesquisa Agropecuária Brasileira, v. 43, p. 11631169, 2008.

Nedelchev, D., E. Raicheva, Y. Petrova, 2003. Characteristics of the productivity of dairy sheep crosses. Animal Science, № 3-4, 111-114. (Bg)

Oravcová, M. 2007. Genetic evaluation for milk production traits in Slovakian Lacaune sheep. Slovak Journal of Animal Science, vol. 40, p. 172179.

Oravcová, M. 2015. Knowledge of milk traits in Slovak dairy sheep. Slovak Journal of Animal Science, vol. 48, (3): p. 140-144.

Oravcová, M. and Peškovičová, D. 2008. Genetic and environmental trends for milk production traits in sheep estimated with Test-day model. Asian Australasian Journal of Animal Science, vol. 21, 2008, p. 1088-1096.

Oravcová, M., E. Groeneveld, M. Kovač, D. Peškovičová and M. Margetín. 2005. Estimation of genetic and environmental parameters of milk production traits in Slovak purebred sheep using test day model. Small Rumin. Res. 56:113-120.

Oravcová, M., M. Margetín, D. Peškovičová, J. Daňo, M. Milerski, L. Hetényi and P. Polák. 2006. Factors affecting milk yield and ewe's lactation curves estimated with test-day models. Czech J. Anim. Sci. 51:483-490.

Oravcová, M., M. Margetín, D. Peškovičová, J. Daňo, M. Milerski, L. Hetényi and P. Polák. 2007. Factors affecting ewe's milk fat and protein content and relationships between milk yield and milk components. Czech J. Anim. Sci. 52:189-198.

Othmane, H., Carriedo, J.A., San Primitivo, F., De La Fuente, L.F., 2002. Genetic parameters for lactation traits of milking ewes: protein content and composition, fat, somatic cells and individual laboratory cheese yield. Genet. Sel. E 34, 581-596.

Pollot G.E., Gootwine E. (2004): Reproductive performance and milk production of Assaf sheep in an intensive management system. J. Dairy Sci., 87 ,3690-3703.

Pollot, G. E., Gootwine, E., 2001. A genetic analysis of complete lactation in improved Awassi sheep. Livest. Prod. Sci. 71, 37-47.

Raicheva, E., T. Ivanova. 2011 . Effect of the Age at Conceiving on the Productivity Traits at Dairy 
Sheep in Bulgaria. Biotechnology in animal husbandry, Vol. 27, № 3, Book 2: 1147-1156.

Raicheva, E., D. Nedelchev, Y. Petrova, 2003. Complex score assessment of dairy sheep productivity. Animal Science, № 1-2, 77-80. (Bg)

Raicheva, E., T. Ivanova, 2010. Duration of lactation and milk production in ewes from synthetic population Bulgarian milk depending on the order of lactation. Animal Science, Supplement 1, 58-63. (Bg)

Raicheva, E., T. Ivanova, 2011 a A previous study on the some parameters connecting whit the milk production at early conceived as ewe lambs from Synthetic Population Bulgarian Milk. Journal of Mountain Agriculture on the Balkans, 4:656-666. (Bg)

Rasali, D. P., J. N. B. Shrestha J. N. B, and G. H. Crow. 2006. Development of composite sheep breeds in the world. Canadian Journal of Animal Science, 86(1): 1-24, 10.4141/A05-073

Safari, A, and Fogarty, N.M. 2003.Genetic Parameters for Sheep Production Traits: Estimates from the Literature. Technical Bulletin 49, NSW Agriculture, Orange, Australia.

Serrano, M., Ugarte, E., Jurado, J.J., Pérez-Guzmán, M.D., Legarra, A., 2001. Test day models and genetic parameters in Latxa and Manchega dairy ewes. Livest. Prod. Sci. 67, 253-264.

Stancheva, N., 2003. Phenotypic and genotypic parameters of selection indices in the Newly Created Milk Sheep Population in Bulgaria. Ph D Thesis, Sofia, pp.188 (Bg)

Stancheva, N., G. Staikova, 2013. Body condition score and productive performance of the Synthetic Population Bulgarian Milk Sheep. J. Animal
Science, Supplement 6, pp 42-46. (Bg)

Stancheva, N., I. Dimitrova, S. Georgieva. 2014. Biological fertility and milk yield in Bulgarian Dairy Synthetic Population sheep according to breeding line, Agricultural Science And Technology, Vol. 6, No 1, Pp 17 - 20.

Stancheva, N., J. Krastanov, Teodora Angelova, G. Kalaydhziev, D. Yordanova, S. Laleva. 2016. Genetic structure of the sheep from the Bulgarian Dairy Synthetic Population on the Experimental Farm of Agricultural Institute - Shumen, Macedonian Journal of Animal Science, Vol. 6, No. 1, pp 17-24.

Stancheva, N., St., Boikovski, G. Stefanova, D. Dimitrov, A. Rusenov, 2006. Regularities in lactation persistency of lactation and possibilities for using part of lactation in tribal work in ewes from Synthetic Population Bulgarian Milk. International Scientific Conference - Stara Zagora, Jine 1-2, Vol. 2. Vet. Medicine, Animal Studies. 244-247. (Bg)

Tibbo, M. 2006. Productivity and health of indigenous sheep breeds and crossbreds in the central Ethiopian highlands. Doctoral dissertation Swedish University of Agricultural Sciences Uppsala. ISSN 1652-6880, ISBN 91-576-7100-1

Walkom, S. F., A. P. Verbyla, F. D. Brien, M. L. Hebart and W. S. Pitchford. 2011. Partitioning genetic variance in composite sheep, Proc. Assoc. Advmt. Anim. Breed. Genet. 19:91-94.

Wolf, J. CBE, Program CBE (Crossbreeding Effects), Version 4.0, Copying 1993, 1994, 1995, 1996, Research Institute of animal production, Department of Genetics and Biometrics, CZ 10400 Prague Uhrineves, Czech Republic

\section{How to cite this article:}

Jivko Krastanov, Nevyana Stancheva, Teodora Angelova, Georgi Kalaydzhiev, Stayka Laleva and Daniela Yordanova. 2018. Genetic Parameters of Milk Yield in Bulgarian Dairy Synthetic Population Sheep. Int.J.Curr.Res.Aca.Rev. 6(4), 1-10. doi: https://doi.org/10.20546/ijcrar.2018.604.001 